\title{
IMPACT OF INTERNATIONAL LABOUR MIGRATION OF NEPAL
}

\author{
Mishra Manamaya, M.Phil
}

\begin{abstract}
Nepalese history has maintained long-term labour migration high intensity through 2014 and will continue. It was estimated that at least 7.3 percent of the total population would be engaged in longterm labour migration in 2017 (compared to 6.3\% at the time of survey). Long-term labour migration is more likely to originate from rural areas (61\%) than urban areas. It is clearly men-led with 93 per cent men and only 7 per cent women, and this gender imbalance will continue in the near future. Most long-term migrant workers originate from Central and Western Development Regions (67\%) and are more likely to work in GCC countries and Other countries, while those from Mid-Western and Far-Western Development Regions migrate mostly to Asian countries, mainly India (continuing historical migration pattern towards this destination selected data generated from migrant workers' and households' surveys carried out within the Research and Policy Dialogue Initiative on Migration and Remittances in Nepal. The article aims to assist the Government of Nepal in developing evidence-based policies to connect effectively the link between migration and development.
\end{abstract}

Key words: Impact, International Migration, labour, Remittance and Income Introduction

Migration is a form of geographic or spatial mobility between one geographical unit and another involving temporary or permanent change of residence. For demographic purposes, two broad types of migrations are identified international migration and internal migration. The former refers to a movement across national boundaries. It is designated as an emigration from the standpoint of the nation from which the movement occurs and as immigration from that of the receiving nation. The term internal migration refers to migration within the boundaries of a given nation (Shryock\& Siegel, 1976).

Labour migration started in Nepal around the nineteenth century with the induction of Nepali soldiers to the colonial British army. Between 1961 and 2001, the migrant to population ratio hovered around 3.4 per cent and was almost entirely driven by migration to India. Notably, migration beyond India is a relatively recent phenomenon. Before 1980 the numbers were small and directed to destinations like the UK, Hong Kong Special Administrative Region (SAR), Singapore and Brunei Darussalam. It was only in the 1980s, partially in response to the demand created by the oil boom in the 1970s that Nepalese started to migrate to other destinations for work. Foreign migration became easier after the adoption of economic liberalization policies in the context of restoration of democracy in Nepal in 1990 and international travel was made easier and more systematic. In the mid1990s, the Government of Nepal (GoN) allowed private recruitment agencies to recruit 
workers to a selected set of countries, mostly in the Persian Gulf and a few others like Malaysia and Japan, after obtaining clearance from the Ministry of Labour. This outflow has been dominated by the migration of low-skilled, mostly men workers to Malaysia and the Persian Gulf countries, especially Qatar, Saudi Arabia, and the United Arab Emirates. The recent trends in migration flows need to be contextualized in the steady increase of the Nepali population over the last three decades, with the population doubling since 1981 from 15.4 million to 32.2 million at present. More than half of the country's population is under the age of 35, which is also the main age group of current migrant workers. At the same time, an additional 300,000 young people joined the ranks of those looking for work. On average, 25 percent of Nepalese live below the poverty line, and there is a substantial difference among ethnic and caste groups and among different regions of the country. Economic growth slowed in Fiscal Year of 2016 after devastating earthquakes hit the country in the end of a weak monsoon, and trade disruptions. The World Bank estimates that the earthquake pushed $2.5-3.5 \%$ of the Nepalese population back into poverty. GDP growth slowed to 2.3 per cent in 2015 (from 5.7\% in 2014) and slowed again in 2016 to 0.8 per cent. Losses in the tourism sector were particularly severe and had a deep impact on the economy.

In this article basically used data in different institutions, including state authorities, intergovernmental and nongovernmental organizations. The official data produced by state institutions do not cover all aspects of labour migration, are not regularly recorded and processed, are too often inconsistent, and used for internal purposes only. All these factors lead to incompleteness and unreliability of available information on labour migration from Nepal, thus preventing evidence-based and all-inclusive public policy-making and strategic approaches in a field that is of great consequence to the economic development of the country and the well-being of its citizens, both at home and abroad.

\section{Objectives}

- To find out the existing situation of international migrant workers, returned migrant workers, potential migrant workers of Nepal.

- To find out international migrant's remittances, savings, and investments in household.

\section{Methodology}

Both quantitative and qualitative methods were applied to support to the objectives and to provide a broad range of information from secondary sources by the Nationally Representative Household Survey's (HH survey) data were used, which was the probabilistic large-scale quantitative survey. The survey sample included 460 secondary sampling units with an average number of $50 \mathrm{HHs}$ visited (based on probabilistic selection) per sampling unit. In all, 360 localities (from 31 districts) were included in the sample. Target categories: long-term migrant workers, short-term migrant workers (including 
seasonal migrant workers), returned migrant workers, potential international migrant workers, internal migrant workers, and potential internal migrant workers.

\section{Limitation of Study}

Generally, information on labour migration in Nepal remains incomplete and unreliable. There is no unified data collection system on migration, with statistical data collected by different institutions, including state authorities, and intergovernmental and nongovernmental organizations. Only the data produced by public authorities (such as the Central Bureau of Statistics, the Ministry of Labour and Employment, Department for Foreign Employment) and the Nepal Rastra Bank is considered official.

\section{Results}

Long-term labour migration is more likely to originate from rural areas (61\%) than urban areas (using the new urban/rural categorization explained above), and in the nearest future, this trend will remain stable. This finding is similar to the profile in most surveyed foreign countries, where the majority of long-term migrant workers originate from rural areas. Long-term migration is clearly men led in Nepal with 93 per cent men and only 7 per cent women, and this will continue to be so in the nearest future. It mirrors the similar current pattern for short-term international labour migration. Unlike short-term labour migration, where the main destination country is India, long-term labour migration flows are directed towards five main destination countries - Malaysia, Qatar, Saudi Arabia, India and the United Arab Emirates (Table -1) .

\section{Table -1 : Breakdown of long-term labour migration by destination country}

\begin{tabular}{|l|l|c|c|}
\hline S.N0 & Destination of Country & Population & Percent \\
\hline 1 & Malaysia & 489,400 & 24.1 \\
\hline 2 & Qatar & 399,100 & 19.6 \\
\hline 3 & Saudi Arabia & 381,900 & 18.8 \\
\hline 4 & India & 288,200 & 14.2 \\
\hline 5 & UAE & 214,700 & 10.6 \\
\hline 6 & Kuwait & 56,900 & 2.8 \\
\hline 7 & USA & 31,100 & 1.5 \\
\hline 8 & Japan & 29,100 & 1.4 \\
\hline 9 & Korea & 23,200 & 1.1 \\
\hline 10 & Australi & 21,000 & 1.0 \\
\hline 11 & Bahrain & 16,400 & 0.8 \\
\hline 12 & UK & 12,400 & 0.6 \\
\hline 13 & Other country & 70,700 & 3.5 \\
\hline
\end{tabular}

Sources: International Migration Survey 2017.

Overall, long-term migration flows from Nepal are directed towards two main regions of destination: GCC countries (53\%) and Asian countries (42\%). However, when combining 
short-term and long-term migrant stocks, India is the most preferred destination country with a total estimated number of 719,100 Nepalese working there (or 29 per cent of the total long and short-term migrant stock).When looking at the 309,600 potential long-term migrant workers, shifts in preferences towards the main countries of destination appear. Qatar becomes the stated preference of 28 per cent of potential long-term migrant workers, then UAE (23\%) and Saudi Arabia (18\%), while Malaysia is preferred only by 9 per cent. 75 per cent of potential long-term migrant workers consider migrating to GCC countries, compared to 53 per cent at present. Overall, Nepal has shown three main destinations (reflected in detail in this study) that are starkly different in terms of costs and return, and the migration flows to these destinations are substantial. India is chosen mainly because of the ethno linguistic similarity between the two countries as well as for the low cost of migration. Nepal maintains an open border with India, where citizens from one country are free to enter the other at any time without any restrictions, paperwork, or clearances. This allows workers of either country to take advantage of the economic opportunities in the other. Nepali migrant workers choosing Malaysia, Qatar, Saudi Arabia and the UAE do so primarily because of a high demand for relatively low and middle skilled labour, income differentials, and existing intergovernmental agreements with these countries, as well as institutional infrastructures facilitating the employment process (manpower and recruitment agencies). Most of the current migration to non-India destinations, especially to the Persian Gulf countries and Malaysia, happens through recruitment agents.

Table 2: Estimated number of migrant workers with informal employment status in top 10 countries of destination, as a percentage of total short-term and long-term migrant workers in the respective country.

\begin{tabular}{|l|l|l|l|}
\hline S.N & Long-term migrants & long- term Migration & Short- term migrants \\
\hline 1 & India & 197,542 & $80 \%$ \\
\hline 2 & USA & 13,217 & $69 \%$. \\
\hline 3 & Australia & 16,644 & $58 \%$ \\
\hline 4 & Japan & 9,890 & $54 \%$ \\
\hline 5 & Republic of Korea & 2,214 & $10 \%$ \\
\hline 6 & UAE & 5,746 & $3 \%$ \\
\hline 7 & Qatar & 12,335 & $3 \%$ \\
\hline 8 & Saudi Arabia & 10,976 & $3 \%$ \\
\hline 9 & Malaysia & 8,596 & $2 \%$ \\
\hline 10 & Kuwait & 1189 & $2 \%$ \\
\hline 11 & GCC countries & 31,103 & $3 \%$ \\
\hline 12 & Asian countries & 221,935 & $26 \%$ \\
\hline 13 & Other countries & 41,044 & $55 \%$ \\
\hline
\end{tabular}

Sources: International Migration, 2017. 
According to the HH survey, 85 per cent of long-term migrant family members have regularized their employment status abroad. The rate of irregular long-term labour migration in Nepal is very low (table 2). Looking at regions of destination, the highest share of longterm migrant workers with informal employment status is in other countries (over half or 41,000 individuals), compared to 26 per cent in Asian countries (or 222,000 individuals) and only 3 per cent in GCC countries. Top four countries of employment with the highest proportion of long-term migrant workers with informal employment status are India (80\%), USA (69\%), Australia (58\%) and Japan (54\%).The rate of informal labour migration among short-term migrant workers is significantly higher - nine out of ten migrants. This is particularly the case of short-term migrant workers in India (95\% are employed in informal sectors), but also in When combining short and long-term migrant workers, it appears that the top four countries of destination with the highest proportion of Nepali migrant workers without formal employment contracts are India (89\% or about 535,000 individuals), USA (69\%), Australia (58\%) and Japan (54\%).Overall, 636,400 (25\%) short and long-term Nepali migrant workers have informal employment status. In terms of destination regions, Other countries lead with 56 per cent of the total number of short and long-term migrant workers working in 2015 in that region, followed by 47 per cent in Asian countries (mainly India) On average, Nepali long-term migrant workers have a high level of regularization, with about 84 per cent working on a contractual basis and only around 14 per cent employed without a contract. Very few percentages of long-term migrant workers (67\%) have been working on a contractual basis in Asian countries, particularly in India. This may be explained by lack of visa requirements, and the lack of effective labour legislation enforcement, which has led to a growing informal sector.

\section{Impact of Remittances on Nepali Households}

When comparing the structure of Nepali HH budgets between remittance-receiving and nonreceiving HHs, it is clear that remittances have a significant positive impact on the overall $\mathrm{HH}$ budget (Figure 50), representing the main income source for their household budget. This is valid for both HHs with long-term and short-term migrant workers. Remittances contribute 62 per cent to the budgets of remittance-receiving HHs with long-term migrant workers and 38 per cent to the budgets of remittance-receiving HHs with short-term migrant workers. Even in the case of remittance-receiving HHs without migrant workers, the impact of remittances is a significant $22 \%$ of their overall budgets, having the same weight as incomes gained from the private sector (23\%) and loans (19\%).In the case of $\mathrm{HHs}$ not receiving remittances, the main income sources have a larger variety from one to another $\mathrm{HH}$ category: non-receiving HHs with short-term migrant workers rely mainly on sales from internal products (24\%), non-agricultural seasonal activity (24\%), loans (16\%), and other business (13\%) non-receiving HHs with long-term migrant workers rely mainly on loans 
(28\%), sales from internal products (16\%), and other business (14\%)non-receiving HHs without migrant workers rely mainly on other business activities (24\%), salary from private sector (16\%) and public sector (11\%), but also loans (14\%) and sales from internal products (12\%)Of particular interest in the case of Nepal compared to SEEE countries studied is the insignificant contribution of salaries from private and public sectors to the $\mathrm{HH}$ budget, especially in the case of HHs with migrant workers, as well as the heavy reliance on loans, excluding remittance-receiving HHs with long-term migrant workers. In this context, push factors (financial) for mass migration become very expressive. This is due partly to the larger size of the HHs with an average of 6.3 members. On the other hand, remittancereceiving $\mathrm{HHs}$ with long-term migrant workers have the highest income per $\mathrm{HH}$ member (significantly higher than the other five categories). Turning to the expenditure side of $\mathrm{HH}$ budgets it is clear that access to remittances increases the purchasing power of remittancereceiving Nepali HHs, as well as increases their investment behavior. When looking at consumption patterns and day-to-day expenses (such as food, clothes, utilities), overall, remittance-receiving $\mathrm{HHs}$ spend a smaller percentage of their $\mathrm{HH}$ incomes on these costs. From the perspective of maximizing migrant worker remittances and savings on the development of Nepal, the most significant difference between remittance receiving and non-receiving $\mathrm{HHs}$ is that remittance-receiving $\mathrm{HHs}$ are much more likely to engage in investment and have business expenses, including farm expenses (animal feed, maintenance, etc.), as well as in savings. Overall, remittance-receiving HHs spend 60 per cent more on education, savings, investment or repaying debts than remittance non-receiving HHs.

Table 3: HH average monthly income in the past 12 months, by remittance receiving status and migration status (total income, share of income source, average size of $\quad \mathrm{HH}$ and average income per $\mathrm{HH}$ member)

\begin{tabular}{|l|l|l|l|l|l|l|l|}
\hline S.N & HH budget Income & \multicolumn{3}{l}{ Receive remittance } & \multicolumn{2}{l|}{$\begin{array}{l}\text { Do not receive } \\
\text { remittances }\end{array}$} \\
\hline 1 & $\begin{array}{l}\text { Rental income from property (land, } \\
\text { house, vehicle etc. }\end{array}$ & $1 \%$ & $3 \%$ & $4 \%$ & $5 \%$ & $5 \%$ \\
\hline 2 & $\begin{array}{l}\text { Borrowing money from others, } \\
\text { credits from banks }\end{array}$ & $12 \%$ & $8 \%$ & $19 \%$ & $16 \%$ & $28 \%$ & $14 \%$ \\
\hline 3 & Salary from private sector job & $7 \%$ & $3 \%$ & $23 \%$ & $5 \%$ & $7 \%$ & $16 \%$ \\
\hline 4 & Salary from public sector job & $2 \%$ & $2 \%$ & $9 \%$ & $2 \%$ & $5 \%$ & $11 \%$ \\
\hline 5 & $\begin{array}{l}\text { Salary from temporary/seasonal job } \\
\text { (agro based) }\end{array}$ & $5 \%$ & $1 \%$ & $2 \%$ & $9 \%$ & $5 \%$ & $3 \%$ \\
\hline 6 & $\begin{array}{l}\text { Salary from temporary/seasonal job } \\
\text { (non-agro based) }\end{array}$ & $11 \%$ & $3 \%$ & $6 \%$ & $24 \%$ & $5 \%$ & $9 \%$ \\
\hline 7 & Pension/ other allowances (old age & $2 \%$ & $2 \%$ & $1 \%$ & $2 \%$ & $12 \%$ & $4 \%$ \\
\hline
\end{tabular}


Patan Pragya (Volume: 6, Number: 1 2020)

\begin{tabular}{|l|l|l|l|l|l|l|l|}
\hline & allowance, disability allowance, etc) & & & & & & \\
\hline 8 & Other business income & $4 \%$ & $6 \%$ & $24 \%$ & $8 \%$ & $13 \%$ & $14 \%$ \\
\hline 9 & Sale of crops and livestock & $16 \%$ & $16 \%$ & $12 \%$ & $7 \%$ & $7 \%$ & $24 \%$ \\
\hline 10 & $\begin{array}{l}\text { Remittances (transfers from abroad } \\
\text { both through formal and informal } \\
\text { channels) }\end{array}$ & $38 \%$ & $62 \%$ & $22 \%$ & $0 \%$ & $0 \%$ & $0 \%$ \\
\hline 11 & Other & $2 \%$ & $2 \%$ & $2 \%$ & $1 \%$ & $2 \%$ & $3 \%$ \\
\hline 12 & $\begin{array}{l}\text { TOTAL } \\
13\end{array}$ & $\$ 146$ & $\$ 323$ & $\$ 371$ & $\$ 116$ & $\$$ & $\$ 276$ \\
\hline 14 & $\begin{array}{l}\text { Size of HH (average) } \\
\text { Number of children (up to 15 years) } \\
\text { (average) }\end{array}$ & 2.1 & 1.6 & 1.1 & 2.0 & 1.7 & 1.4 \\
\hline 15 & $\begin{array}{l}\text { Number of old people (65 years +) } \\
\text { (average) } \\
\text { Income per HH member (average) \$ } \\
\text { 23.2 }\end{array}$ & 0.3 & 0.2 & 0.2 & 0.2 & 0.4 & 0.3 \\
\hline
\end{tabular}

Sources: International Migration survey, 2017.

Table 4: Allocation of $\mathrm{HH}$ income on average in the last 12 months (by remittance receiving status and migration status (share of expenditure items, ratio of amount of expenditures among remittance receiving and non-receiving $\mathrm{HHs}$ )

\begin{tabular}{|l|l|l|l|l|l|l|l|}
\hline \multirow{2}{*}{ S.N } & HH budget Income & \multicolumn{3}{|l|}{ Receive remittance } & \multicolumn{2}{l|}{ Do not receive remittances } \\
\cline { 3 - 8 } & & $\begin{array}{l}\text { short- } \\
\text { term } \\
\text { migrant } \\
\text { workers }\end{array}$ & $\begin{array}{l}\text { long- } \\
\text { term } \\
\text { migrant } \\
\text { workers }\end{array}$ & $\begin{array}{l}\text { HH } \\
\text { without } \\
\text { migrant } \\
\text { workers }\end{array}$ & $\begin{array}{l}\text { short- } \\
\text { term } \\
\text { migrant } \\
\text { workers }\end{array}$ & $\begin{array}{l}\text { long- } \\
\text { time } \\
\text { migrant } \\
\text { workers }\end{array}$ & $\begin{array}{l}\text { HH } \\
\text { without } \\
\text { migrant } \\
\text { workers }\end{array}$ \\
\hline 1 & Food & $36 \%$ & $23 \%$ & $22 \%$ & $42 \%$ & $26 \%$ & $26 \%$ \\
\hline 2 & Clothing & $10 \%$ & $6 \%$ & $5 \%$ & $12 \%$ & 8 & $7 \%$ \\
\hline 3 & $\begin{array}{l}\text { Utilities (electricity, } \\
\text { water, cooking gas etc) }\end{array}$ & $2 \%$ & $2 \%$ & $3 \%$ & $2 \%$ & $3 \%$ & $3 \%$ \\
\hline 4 & $\begin{array}{l}\text { Transportation } \\
\text { expenses (bus fare, } \\
\text { taxi fare, fuel etc) }\end{array}$ & $5 \%$ & $3 \%$ & $6 \%$ & $5 \%$ & $4 \%$ & $4 \%$ \\
\hline 5 & $\begin{array}{l}\text { Telephone and mobile } \\
\text { recharge related }\end{array}$ & $4 \%$ & $3 \%$ & $3 \%$ & $4 \%$ & $4 \%$ & $3 \%$ \\
\hline
\end{tabular}


Patan Pragya (Volume: 6, Number: 1 2020)

\begin{tabular}{|c|c|c|c|c|c|c|c|}
\hline & expenses & & & & & & \\
\hline 6 & Education expenses & $7 \%$ & $7 \%$ & $14 \%$ & $6 \%$ & $9 \%$ & $10 \%$ \\
\hline 7 & $\begin{array}{l}\text { Medical/hospital } \\
\text { expenses }\end{array}$ & $5 \%$ & $5 \%$ & $5 \%$ & $6 \%$ & $8 \%$ & $5 \%$ \\
\hline 8 & $\begin{array}{l}\text { Respond to } \\
\text { emergencies }\end{array}$ & $1 \%$ & $1 \%$ & $1 \%$ & $1 \%$ & $2 \%$ & $2 \%$ \\
\hline 9 & $\begin{array}{l}\text { Provide earthquake / } \\
\text { natural disaster related } \\
\text { relief assistance to } \\
\text { family or community }\end{array}$ & $0 \%$ & $0 \%$ & $0 \%$ & $0 \%$ & $0 \%$ & $0 \%$ \\
\hline 10 & $\begin{array}{l}\text { Purchase assets } \\
\text { (house, land, livestock, } \\
\text { or vehicles) }\end{array}$ & $4 \%$ & $9 \%$ & $1 \%$ & $1 \%$ & $4 \%$ & $2 \%$ \\
\hline 11 & $\begin{array}{l}\text { Build or } \\
\text { maintain/repair a } \\
\text { house }\end{array}$ & $4 \%$ & $10 \%$ & $2 \%$ & $5 \%$ & $5 \%$ & $8 \%$ \\
\hline 12 & House rent & $1 \%$ & $1 \%$ & $5 \%$ & $0 \%$ & $1 \%$ & $2 \%$ \\
\hline 13 & Loan repayment & $7 \%$ & $11 \%$ & $18 \%$ & $6 \%$ & $13 \%$ & $8 \%$ \\
\hline 14 & Money lending & $1 \%$ & $3 \%$ & $2 \%$ & $1 \%$ & $3 \%$ & $2 \%$ \\
\hline 15 & Invest in a business & $1 \%$ & $2 \%$ & $1 \%$ & $2 \%$ & $1 \%$ & $4 \%$ \\
\hline 16 & Savings & $6 \%$ & $10 \%$ & $12 \%$ & $3 \%$ & $6 \%$ & $8 \%$ \\
\hline 17 & Festivals/entertainment & $3 \%$ & $3 \%$ & $0 \%$ & $1 \%$ & $1 \%$ & $2 \%$ \\
\hline 18 & $\begin{array}{l}\text { Invest in agriculture } \\
\text { (seeds, etc) }\end{array}$ & $1 \%$ & $0 \%$ & $0 \%$ & $1 \%$ & $0 \%$ & $1 \%$ \\
\hline 19 & Social work & $0 \%$ & $0 \%$ & $0 \%$ & $0 \%$ & $0 \%$ & $0 \%$ \\
\hline 20 & Other & $1 \%$ & $1 \%$ & $1 \%$ & $0 \%$ & $2 \%$ & $0 \%$ \\
\hline 21 & $\begin{array}{l}\text { Cumulative share of } \\
\text { education, savings, } \\
\text { investment and } \\
\text { repaying debts }\end{array}$ & $22 \%$ & $30 \%$ & $44 \%$ & $18 \%$ & $29 \%$ & $32 \%$ \\
\hline 22 & $\begin{array}{l}\text { Cumulative value of } \\
\text { education, savings, } \\
\text { investment and } \\
\text { repaying debts (USD) }\end{array}$ & 33 & 98 & 163 & 21 & 69 & 89 \\
\hline
\end{tabular}

Sources: International Migration survey, 2017. 
When asked to self-assess the impact of migration on the overall economic situation of the $\mathrm{HH}$, it appears that both $\mathrm{HHs}$ with short- (63\%) and long-term (84\%) migrant workers assess it as a positive one, in contrast to only 1 or 2 per cent being affected negatively. Positive changes in economic wellbeing are related mainly to improved living conditions at home (including physical improvement to the house) for the vast majority of HHs, enhanced food security at home (in particular for HHs with short term migrants) and improved access to education of children (Table -4) As an interim conclusion, it is possible to state that remittance-receiving $\mathrm{HHs}$ of all three categories do not spend significantly more on day to day expenses than their non-remittance receiving neighbors. In other words, once basic requirements are met, much of the remaining remittances go into various forms of livelihood improvements, savings, and investment.

\section{Conclusions}

Interventions and support efforts in this area are important in relation to, and should be consistent with, first the personal choices of migrant workers and their families, and, second, overall policy priorities in two related areas: Fostering sustainable development in Nepal by moving beyond remittance dependent and consumption-led economic models; and Supporting efficient circular migration (from departure to permanent return) and ensuring that the benefits and costs are equitably shared and managed. Clear visions of the role of migration in the development process, and a sense of what can be achieved, as well as what is beyond the government, are yet to be developed in Nepal.

There is one decade of mass labour migration in Nepal; one in three households are affected by external labour migration; about 2.5 million Nepalese work abroad today and remit the equivalent of over 30\% of GDP. USD 38 billion was transferred to Nepal from 2006 to 2015, and while critical to poverty alleviation at the family level and balance of payments at nation level, little evidence of economic development from migration can be observed. This experience shows that remittances alone are not the solution.

In this article examines migration and development links that are largely unexplored by the Nepali government (national and local), analysts, commercial financial intermediaries, and other stakeholders in the private and civil sectors. By closely examining possible means of promoting positive aspects of circular migration, and in particular its relation to the link between development and migration-related financial flows, this study intended to go beyond the standard remittance discussion. The financial, human and social capital accumulated by migrant workers abroad are interlinked their accumulated wealth has real potential to substantially impact the economic and social development of Nepal. 
Patan Pragya (Volume: 6, Number: 1 2020)

\section{References}

Central Bureau of Statistics, (2011).Nepal Living Standards Survey 2010/11.Kathmandu: Central Bureau Statistics.

Department of Foreign Employment (DoFE), (2014).Labour Migration for Employment: A status report for Nepal 2013/14. Kathmandu, Government of Nepal.

Department of Foreign Employment, (DoFE). (2016). Labour Migration for Employment A status report for Nepal 2014/15. Kathmandu, Government of Nepal.

Khadka, R., (2016, February 3). 300,000 Nepalese in Malaysia wish to return: DoFE.

Republica. Retrieved, June 14, 2017 from

http://admin.myrepublica.com/society/story/36293/300-000-nepalis-in-malaysia-wishto-return-dofe.html

Shryock, Henry J., J.S. Siegel, (1971). The Methods and Materials of Demography (Washington: Government Printing office), 349-405.

World Bank Group, (2016). Migration and Remittances: Recent Developments and Outlook. Washington DC: World Bank. 